\section{Elevation of a patient's trunk and legs does not influence length of stay in the post- anesthesia care unit}

Post-anesthesia care unit, Hospital das Clinicas, Faculdade de Medicina da Universidade de São Paulo, São Paulo, Brazil
- Otávio Omati

- Fábio Ely Martins Benseñor

- Joaquim Edson Vieira

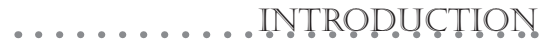

Patient recovery time after anesthesia depends on problem-oriented monitoring and individual assessment. The post-anesthesia care unit provides state-of-the-art setup, equipment and facilities to care for patients recovering from anesthesia.

The type of anesthesia administered has little influence on the need for post anesthesia care. This implies that the post-anesthesia care unit may sometimes be overloaded, thereby imposing the risk of jamming of the patient flow through this hospital unit. In addition, such overloading in this unit may delay the hospital's operating room schedule. Among the reasons for low bed availability in the postanesthesia care unit are clinical assessments that may be slow-paced and low discharge rates due to reduced nursing staff availability. ${ }^{1}$

Ideally, all the patients coming from the surgical theater should be indicated for recovery within the post-anesthesia care unit. Patient transportation and admission are under the responsibility of anesthesiologists, who perform a first physical evaluation and give guidance to nursing staff for them to follow clinical recovery patterns, as indicated by the Aldrete-Kroulik modified scale. ${ }^{2}$

Ponhold and Vicenzi have shown that there was lower incidence of bradycardia during recovery from spinal anesthesia when patients were allowed to stay in a position with their trunk and legs elevated at 30 degrees (hammock position). ${ }^{3}$ Since a stable heart rate is one of the determinants of full recovery from anesthesia within the postanesthesia care unit, it seemed reasonable to consider whether the patient position could influence the duration of the recovery during the post-anesthesia care period.

The distinct supervision care adopted by some anesthesiologists, in relation to the post-anesthesia patient position, has created a natural environment for investigating whether different patient positions would give rise to differences in the time required for recovery. The objective of this study was to investigate whether modifying the patient's position when recovering from anesthesia would shorten the postoperative recovery time in the post-anesthesia care unit.

................ METHODOS

The present study was performed at Hospital das Clínicas, Universidade de São Paulo, a tertiary-level public hospital. The study protocol was approved by the institution's Ethics Committee. This investigation was designed as a retrospective study, since there would not be any possibility of intervention regarding the recovery position for the patients admitted to the post-anesthesia care unit. Patients admitted to the post-anesthesia care unit had their post-anesthesia recovery time recorded by means of the nurse's registering system in that unit. Only the patients kept in the supine horizontal position or with their trunk and legs elevated at 30 degrees (hammock position) were considered for this study. Patients in any other position were not included. Pregnant women and patients under the age of twelve years old were also excluded. All patients in this unit were positioned on a bed with no pillow.

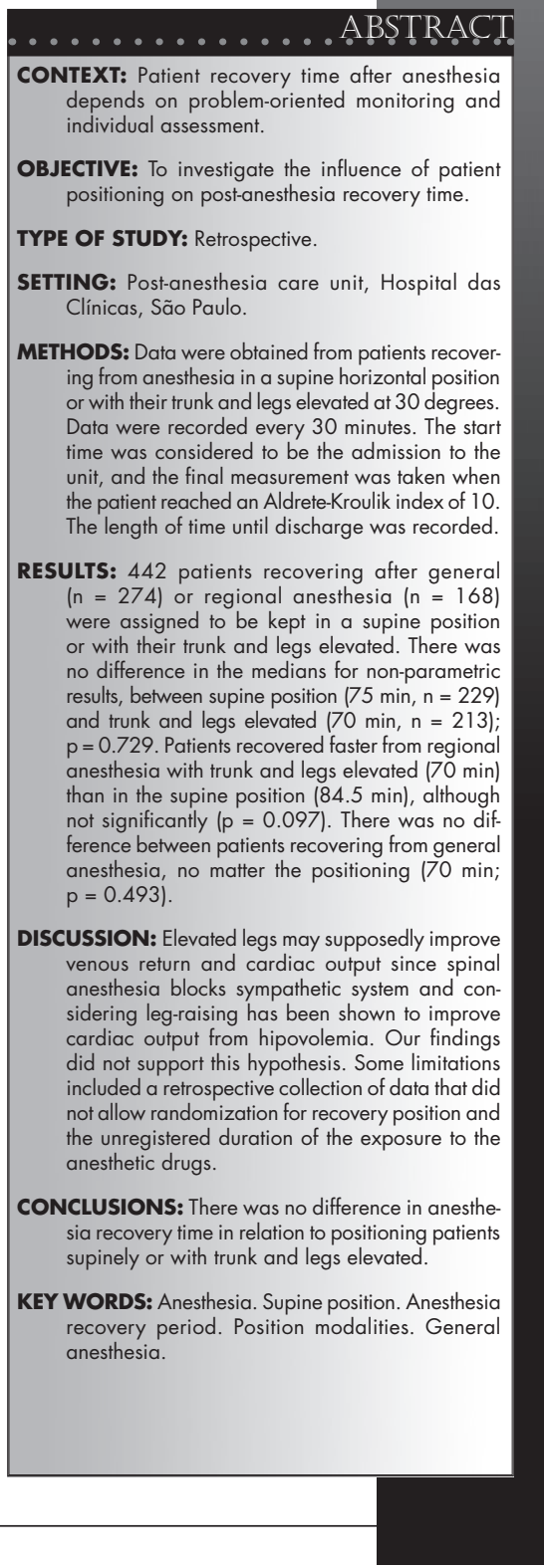


Patients' demographic data and the type of anesthesia they had been given were recorded. The recovery period was defined as the period between admission to the post-anesthesia care unit and the time when the discharge criteria according to the Aldrete-Kroulik scale were reached. It did not include the period between reaching the discharge criteria and the moment when the patient left the unit. The nursing staff assessed patients on the AldreteKroulik scale every thirty minutes. Patients received analgesics and intravenous fluid when indicated by the anesthesiologist responsible for the post-anesthesia care unit.

The ideal discharge moment was considered to be when the patient reached a level of 10 , according to the modified Aldrete-Kroulik post-anesthesia recovery scale. This scoring system includes the following factors (scores indicated in brackets):

1. Limb movements: no movement in any of the four limbs (0), no movement in two limbs (1), movement restored in all limbs (2);

2. Awareness response: not responding to his/her name (0), a response to his/her name (1), completely awake (2);

3. Blood pressure measurement: less than $20 \%$ of what was recorded before anesthetizing (0), between $20 \%$ and $50 \%$ (1), more than $50 \%$ of the pre-anesthesia blood pressure (2);
4. Peripheral hemoglobin saturation: less than $90 \%$ with oxygen supply under facial mask (0), more than $90 \%$ with oxygen supply under facial mask (1), more than $90 \%$ in room air (2);

5. Breathing pattern: apnea (0), hypoventilation or dyspnea (1), deep breathing and cough capability (2). can reach a maximum of ten, thereby establishing a patient's final condition as fully recovered from anesthesia. ${ }^{2}$ However, the discharge criteria also include well-established general conditions such as absence of nausea or vomiting, and also good control over pain.

The lengths of stay were compared via the Mann-Whitney rank sum test, since there was no normal distribution for the recovery time, and the significance level was set at $95 \%$. For patients under regional anesthesia, the Kruskal-Wallis analysis of variance (ANOVA) of ranks and Dunn's test were performed. Demographic data was evaluated using Student's t test, with the significance level set at $95 \%$. [when $\mathrm{p}$ value is $<0.05$ ]

................... RESULTS

During the months of January through March 2002, approximately 1,050 patients were admitted to the post-anesthesia care unit
The sum of the Aldrete-Kroulik criteria

of Hospital das Clínicas. From this total, 442 patients were included in this study protocol, of whom 229 were kept in a supine position and 213 with their trunk and legs elevated.

Of these 442 patients, 274 had undergone general anesthesia and 168 regional anesthesia (with bupivacaine). The patients who received regional anesthesia were significantly older $(50.2 \pm 16.1)$ than those under general anesthesia $(42.5 \pm 17.3)$, by Student's $\mathrm{t}$ test $(\mathrm{p}<0.001$; mean $\pm \mathrm{SD})$. There was no difference in body mass index between patients under regional anesthesia $(25.3 \pm 5.1)$ and those under general anesthesia $(24.4 \pm$ 4.6) $(\mathrm{p}=0.062)$. In relation to the recovery position utilized, there was no difference for age $(\mathrm{p}=0.363)$ or body mass index ( $\mathrm{p}$ $=0.310$ ). Age and body mass index data are shown in Table 1 .

The data on the length of stay in the postanesthesia care unit were considered to be nonparametric. Thus, the median stay was utilized for the comparison of the supine position with elevated trunk and legs, together with the range from the $25^{\text {th }}$ to the $75^{\text {th }}$ percentile. The results showed that there was no difference in length of stay between patients in the supine position (median $=75 \mathrm{~min}$; range: $50-108)$ or with elevated trunk and legs (70 min; range: 45-110), by the Mann-Whitney test $(\mathrm{p}=0.729)$.

Patients recovered faster from regional anesthesia when the trunks and legs were elevated (70 $\mathrm{min}$; range: $46-110)$ than when they were in the supine position $(84.5 \mathrm{~min}$; range: 60-130), although this was not statistically significant $(\mathrm{p}=0.097)$. However, there was no difference in patients' recovery rate following general anesthesia, no matter which position was utilized. It is interesting to notice that, although the recovery time in the supine horizontal position was faster for general (70 min; range: 45-95) than for regional anesthesia cases (84.5 min; range: $60-130)(\mathrm{p}=0.008)$, patients recovering from regional anesthesia seemed to recover faster with their trunk and

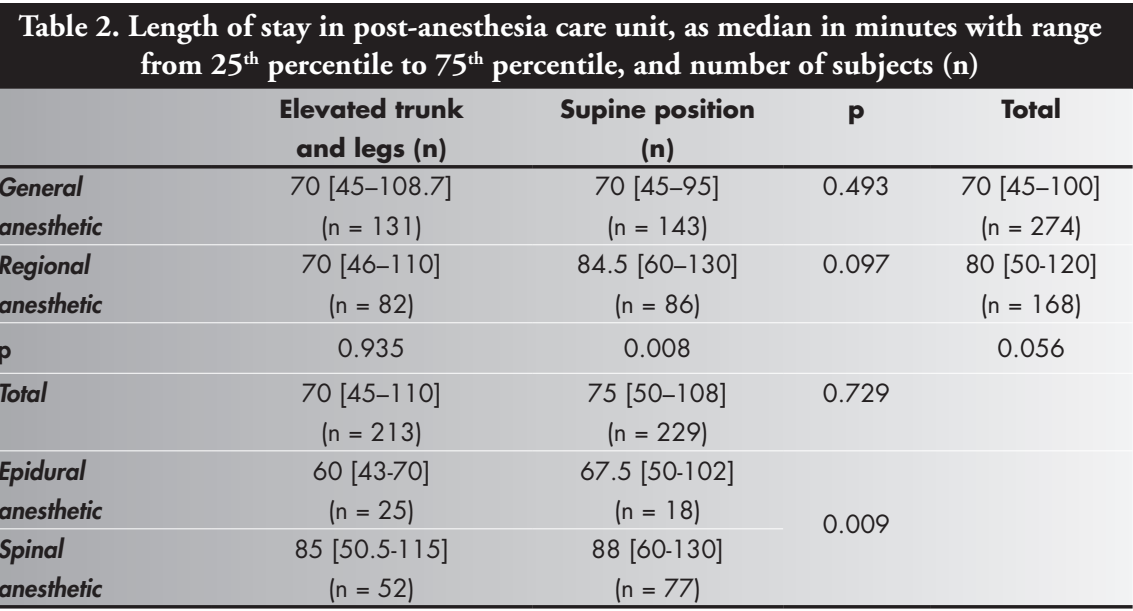

legs elevated $(\mathrm{p}=0.009)$ (Table 2$)$.

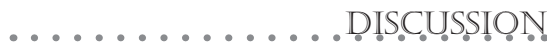

In the present study, the patient's body position during the post-anesthesia care period did not influence the recovery time at the post-anesthesia care unit. The patients who received regional anesthesia were older than those assigned for general anesthesia in this selected sample. This could be considered to be the result of differences in disease incidence. Regional anesthesia is commonly indicated for surgical procedures on the lower abdomen, 
such as in the treatment of urogenital disease, for which the prevalence may be higher among the elderly. Nevertheless, the younger patients did not show a better recovery time, for either position investigated. There was no difference in the recovery time after general anesthesia when using the supine position or elevating the trunk and legs position (70 minutes in each case), but the recovery was longer following regional anesthesia when the supine position was utilized. This longer recovery time may have resulted from the large proportion of the sample that underwent spinal anesthesia and were assigned to the supine position.

Spinal anesthesia blocks the pre-ganglionic sympathetic system and hence reduces cardiac output. This physiological effect comes from the reduced stroke volume and vein dilation. ${ }^{4}$ It also reduces the release of catecholamines from the adrenal medulla when a blockade of efferent autonomic pathways is achieved. ${ }^{5}$ These possibilities might add to the physiological supposition that elevated legs may improve venous return and cardiac output. It has been reported, however, that neither leg elevation nor the Trendelenburg body position influences the autonomic cardiac control among wakeful and non-anesthetized volunteers. ${ }^{6}$

Passive leg-raising has commonly been used for the initial treatment of hypovolemic shock. However, there are reports that have pointed out that this does not produce any significant auto-transfusion effect, including in patients with coronary artery diseases. ${ }^{7}$ Although the controversy may remain, the leg-raising maneuver may be capable of increasing stroke volume and cardiac output in hypovolemic humans. ${ }^{8}$ In addition, the stroke index of a patient in a seated position does not differ from the supine position when recovering from exercise, when the systemic vascular resistance index decreases. ${ }^{9}$ Since a patient under regional anesthesia can experience significant decrease in total peripheral resistance in association with reduced venous return, it would be reasonable to consider that the position with trunk and legs elevated can add to the recovery of the patient's hemodynamic homeostasis.

It is important to note that the patients in the regional anesthesia group received only one local anesthetic (bupivacaine), administered either spinally or epidurally. This makes the regional anesthesia group comparable. However, interestingly, it can at the same time bring some limitations. The use of 20 $\mathrm{mg}$ of $0.5 \%$ bupivacaine as a spinal blockade can result in a period of up to 380 minutes for complete resolution of anesthesia, while a greater quantity $(150 \mathrm{mg})$ of the same solution, for epidural blockade, can reach a longer blockade time of up to 460 minutes. ${ }^{10}$ This would cause a patient who received epidural anesthesia to take longer to recover, considering the Aldrete-Kroulik criteria.

When the patients that received regional anesthesia were classified according to whether they underwent a spinal or an epidural procedure, each subgroup was very small. Surprisingly, it was possible to observe that there were patients with a longer recovery time after receiving spinal bupivacaine (Table 2). Notwithstanding these results, patients in the post-anesthesia unit with their trunk and legs elevated recovered faster than those in the supine position, either after spinal or after epidural anesthesia.

There are some limitations relating to the retrospective method adopted. This design could have imposed a bias on the results, since the duration of the exposure to the anesthetic drugs, which would provide better control over the anesthesia technique, was not recorded. To address the possibility that the quantity of anesthetic drugs might influence recovery time, a prospective and randomized study would bring greater quality to further investigation. Also, the retrospective collection of data did not allow randomization to be performed, although the final distributions of patients' positions were close for the same group considered (regional or general anesthesia). Finally, the time intervals for measuring the Aldrete-Kroulik index (every 30 minutes), might have imposed some degree of imprecision on the results. A shorter interval would allow a more precise determination of the timing of the anesthesia recovery. The fact that the data were retrospective and came from the nursing records of Aldrete-Kroulik indexes may have blunted their precision.

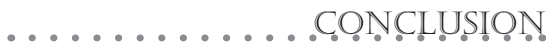

The patient's body position during the post-anesthesia period did not influence the recovery time at the post-anesthesia care unit. There was no difference in the duration of patients' post-anesthesia recovery in relation to using the supine position or elevating the trunk and legs at 30 degrees. The faster recovery from general anesthesia could be expected, given the Aldrete-Kroulik criteria.

\footnotetext{
1. Tessler MJ, Mitmaker L, Wahba RM, Covert CR. Patient flow in the Post Anesthesia Care Unit: an observational study. Can J Anaesth. 1999;46(4):348-51.

2. Aldrete JA, Kroulik D. A postanesthetic recovery score. Anesth Analg. 1970;49(6):924-34.

3. Ponhold H, Vicenzi MN. Incidence of bradycardia during recovery from spinal anaesthesia: influence of patient position. Br J Anaesth. 1998;81(5):723-6.

4. Ward RJ, Bonica JJ, Freund FG, Akamatsu T, Danziger F, Englesson S. Epidural and subarachnoid anesthesia: Cardio-

vascular and respiratory effects. JAMA. 1965;191(4):275-8.

5. Kehlet $\mathrm{H}$. Influence of regional anaesthesia on postoperative morbidity. Ann Chir Gynaecol. 1984;73(3):171-6.

6. McHugh GJ, Robinson BJ, Galletly DC. Leg elevation compared with Trendelenburg position: effects on autonomic cardiac control. Br J Anaesth. 1994;73(6):836-7.

7. Kyriakides ZS, Koukoulas A, Paraskevaidis IA, et al. Does passive leg raising increase cardiac performance? A study using Doppler echocardiography. Int J Cardiol. 1994;44(3):288-93.

8. Wong DH, O'Connor D, Tremper KK, Zacari J, Thompson
}

P, Hill D. Changes in cardiac output after acute blood loss and position change in man. Crit Care Med. 1989;17(10):979-83.

9. Kilgour RD, Mansi JA, Williams PA. Cardiodynamic responses during seated and supine recovery from supramaximal exercise. Can J Appl Physiol. 1995;20(1):52-64.

10. Bernards CM. Epidural and Spinal Anesthesia. In: Barash PG, Cullen BF, Stoelting RK, editors. Clinical Anesthesia, 4th Ed. Philadelphia: Lippincott Williams \& Wilkins, 2001. Ch. 26, p: 1-43. Available at URL: http://pco.ovid.com/lrppco/index. html, accessed in 2003 (Aug 28). 


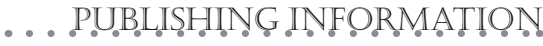

Presented at the $49^{\text {th }}$ Meeting of the Brazilian Society of Anesthesiology, Joinville, Santa Catarina, 2002.

Otávio Omati, MD. In-training resident physician, Anesthesiology Training Center, Hospital das Clínicas, Faculdade de Medicina da Universidade de São Paulo, São Paulo, Brazil.

Fábio Ely Martins Benseñor, MD, PhD. Supervisor of post-anesthesia care unit, Anesthesiology Division, Hospital das Clínicas, Faculdade de Medicina da Universidade de São Paulo, São Paulo, Brazil.

Joaquim Edson Vieira, MD, PhD, TSA-SP. Attending physician, Anesthesiology Division, Hospital das Clínicas, and collaborating professor, Internal Medicine Department, Faculdade de Medicina da Universidade de São Paulo, São Paulo, Brazil. Holder of Superior Title in Anesthesiology (TSA-SP), Brazilian Society of Anesthesiology.

Sources of funding: Not declared

Conflict of interest: None

Date of first submission: September 8, 2003

Last received: June 22, 2004

Accepted: June 22, 2004

\section{Address for correspondence:}

Joaquim Edson Vieira

$$
\begin{aligned}
& \text { Av. Dr. Arnaldo, } 455 \text { - Sala } 1216 \\
& \text { São Paulo (SP) - Brasil - CEP } 01246-903 \\
& \text { Tel. 1+ } 55 \text { 11) 3066-7317 } \\
& \text { Fax 1+ } 55 \text { 11) 3085-0992 } \\
& \text { E-mail: joaquimev@hotmail.com }
\end{aligned}
$$

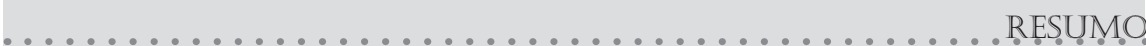

A elevação do tronco e membros inferiores não influencia tempo de permanência na Unidade de Recuperação Pós-Anestésica

CONTEXTO: A recuperação após anestesia depende de monitorização padronizada e de avaliaçôes individuais.

OBJETIVO: Investigar a influência do posicionamento do paciente sobre o tempo de recuperação pós-anestesia geral e regional.

TIPO DE ESTUDO: Retrospectivo.

LOCAL: Unidade de Recuperação Pós-Anestésica, Hospital das Clínicas de São Paulo.

MÉTODOS: Pacientes receberam cuidados de enfermagem sob supervisão de anestesiologista na Unidade de Recuperaçāo Pós-Anestésica quando em posição supina ou com tronco e pernas elevadas em 30 graus a cada 30 minutos. O início da contagem de tempo foi na admissão à unidade e a última medida foi tomada quando paciente recebeu nota 10 na escala de Aldrete-Kroulik. O período de tempo até receber alta foi registrado.

RESULTADOS: 442 pacientes recuperaram-se após anestesia geral $(\mathrm{n}=274)$ ou regional $(n=168)$, posicionados em supino ou com tronco e pernas elevadas. A mediana para resultados não-paramétricos não mostrou diferença no tempo de permanência quan- do em supino ( $75 \mathrm{~min}, \mathrm{n}=229)$ ou com tronco e pernas elevados $(70 \mathrm{~min}, \mathrm{n}=213$, $p=0,729)$. Pacientes recuperaram mais rapidamente de anestesia regional quando com tronco e pernas elevadas $(70 \mathrm{~min})$ do que em supino ( $84.5 \mathrm{~min}$ ) embora sem significância estatística $(p=0,097)$. Não houve diferença na recuperação da anestesia geral em qualquer posição investigada (70 min, $p=0,493$ ).

DISCUSSÃO: A elevação das pernas em posição supina pode aumentar o retorno venoso pois a anestesia do neuro-eixo bloqueia o sistema simpático e essa manobra mostrou-se capaz de promover melhor débito cardíaco durante hipovolemia. Os achados deste estudo não comprovam esta hipótese. No entanto, algumas limitaçōes deste estudo se aplicam, como uma coleta retrospectiva, impedindo aleatorização dos grupos de recuperação, bem como a ausência de registro do tempo de exposição aos anestésicos.

CONCLUSỐES: Não houve diferença para o tempo de recuperação pós anestesia considerando o posicionamento do paciente.

PALAVRAS-CHAVE: Anestesia. Período de recuperação da anestesia. Modalidades de posição. Decúbito dorsal. Anestesia geral. 